\title{
Characterisation of Domestic Sewage from an Estate in Warri, Nigeria
}

\author{
I.E. Uwidia \& C.M.A. Ademoroti \\ Department of Chemistry, University of Benin, Benin City, Nigeria \\ E-mail: uwidiaie@yahoo.com
}

Received: January 26, 2011 Accepted: February 14, 2011 doi:10.5539/ijc.v3n3p81

\begin{abstract}
Samples of domestic sewage obtained from an estate located in Warri, Nigeria were analysed for selected pollution characteristics viz:

Electrical conductivity (EC), Suspended Solids (SS), Dissolved Solids (DS), Total Solids (TS), Permanganate Value (PV), Biochemical Oxygen Demand (BOD) and Chemical Oxygen Demand (COD).

Values of the characteristics obtained in both wet and dry seasons showed that EC ranged between $220.6 \mathrm{uScm}^{-1}$ and $367.0 \mathrm{uScm}^{-1}$, SS ranged between $200 \mathrm{mg} / \mathrm{L}$ and $380.0 \mathrm{mg} / \mathrm{L}$, TS had values between $162.2 \mathrm{mg} / \mathrm{L}$ and 286.0 $\mathrm{mg} / \mathrm{L}$, BOD ranged between $163.7 \mathrm{mg} / \mathrm{L}$ and $220.7 \mathrm{mg} / \mathrm{L}$ and COD ranged between $286.2 \mathrm{mg} / \mathrm{L}$ and $355.6 \mathrm{mg} / \mathrm{L}$. Analysis revealed that high values occurred during the wet season compared with low values in the dry season months.

Values of the pollution characteristics show that the water is polluted. Treatment before disposal or reuse is necessary so as to prevent health, and environmental pollution hazards.
\end{abstract}

Keywords: Domestic sewage, Characterization, Pollution, Treatment, Disposal

\section{Introduction}

Sewages are generated daily by man in the process of meeting his various living requirements. Generally sewage can be described as wastewater from a community. Wastewater refers to spent or used water containing dissolved or suspended matter. Wastewater from residential areas is referred to as domestic sewage (Porteous, 2000). It consists of pollutants such as human wastes (faeces and urine) and sullage. The term sullage refers to wastes arising from food preparation and cleaning of kitchen utensils laundry and floor drain wastes. Sewage from various homes and institutions (private and public) in a community constitute municipal sewage (Ademoroti, 1996a).

Domestic sewage is therefore a complex mixture containing water together with common constituents such as organic and inorganic matter and microorganisms. Proteins and carbohydrates from these sources are biodegradable and they constitute 90 percent of the organic matter in domestic sewage. If wastes generated by man are left untreated, various pollutants which are potentially harmful would be released to the environment. Pollution, a problem caused by man is gross contamination of an environment causing harmful or potentially harmful effects in the total ecological community. The future of man depends upon the state of his environment. The complexity of our environment is due to various human activities which gradually results in the deterioration of the entire environment.

Various factors are responsible for pollution such as domestic sewage, agricultural wastes, together with industrial and commercial effluents. These wastes are discharged directly into the environment such as water bodies e.g. rivers, streams, lakes etc. A receiving water body becomes grossly polluted, aquatic life forms in them die and this in turn affects the life of man who depends on the water (Ademoroti, 1996b).

\subsection{Sewage disposal problems}

The impact of sewage disposed on the environment has become a threat to the existence of plant and animals and ultimately to the quality of human life. Pollution threatens the natural environment and poses real danger to human life. It is causing widespread concern and has become an important area of interest in the field of modern research. Pollution problem is worse in developing countries like Nigeria where indiscriminate wastewater disposal is mostly practiced. 
Typically domestic sewage contains not only organic and inorganic matter but also bacteria, viruses and other parasites which are pathogenic. It also contains oil and grease, nutrients, heavy metals etc. The pathogenic organisms are disease-causing. One of the ways that pathogens cause disease is through the production of poisonous substances called toxins. Not all pathogens produce toxins but the characteristic of producing toxins and their potency are major factors in the capacity of microorganisms to cause disease. They grow and multiply fast in the intestinal tracts of their hosts e.g. man and animals (Geldereich, 1978). The faeces of such infested person if released into a water body through indiscriminate sewage disposal can cause epidemic leading to loss of lives.

Organic pollution from domestic sewage can pose serious environmental health problems. Water contact and water-borne, water-related diseases are caused by this type of pollution (Snoeyink \& Jenkins, 1980). Examples of some common types of these diseases are schistosomiasis, leptospirosis, tularaemia, cholera, hepatitis, dysentery, diarrhea, typhoid guinea worm infection e.tc. Epidemics of these diseases occur periodically in many parts of the world (Henry \& Heinke, 1989; Ademoroti, 1996a).

Discharge of biodegradable organic substances in water can lead to oxygen depletion in the receiving water and consequently, death of aquatic life (Fox \& Gerald, 1981). Inorganic nutrients such as nitrates and phosphates can cause excessive algae growth. These algae now become pollutants in the water bodies. At this point, the water becomes unsafe for drinking and recreation (e.g. swimming or bathing). Excessive algae growth can have a detrimental aesthetic effect on water. The dying off and mineralization of the algae, may lead to the death of aquatic life due to oxygen depletion. This is because oxygen in the water is used for decomposition of dead algae in the water. The decaying plant and algae add colour, odour, turbidity and objectionable taste to water.

The cost of pollution control is extremely high. It has been estimated that in the United States alone, the annual cost is close to $\$ 5$ billion, in addition to the thousands of death and illness which are caused by it (Steward \& Towse, 1984).

Moreover, its effects are international therefore, international solutions to the problems are necessary if the world is to be left a fit place for future generation to live in.

International bodies such as United Nations Environment Program and World Health Organization (WHO) are established with a view of using regulations and publications to lesson the problems of pollution either on land, in water bodies or in the atmosphere.

Sewage disposal is a worldwide problem and there is therefore need to effect proper treatment to the sewage before disposal. Treatment of domestic sewage before disposal helps to prevent pollution of the entire ecosystem and thus preserve our water for beneficial uses (Weber Jr., 1972).

\subsection{Justification of the study}

Raw sewage imposes organic loading on streams and water-causes. In a developing country like Nigeria sewage from most communities is discharged directly to streams and rivers without treatment. The result is accumulation of sludge and development of offensive odours with unsightly conditions. Odours are one of the most serious environmental concerns to the public (Metcalf \& Eddy, 2001).

Discharge of contaminants to the environment is receiving close scrutiny by public health and regulatory agencies. New regulations that restrict the discharge of such contaminants are being promulgated. Treatment of sewage before disposal has therefore become a significant challenge. Such treatment will help to reduce pollution problems and create a good and healthy environment.

This work is aimed at characterizing the domestic sewage obtained from an estate located in Warri, Nigeria in order to asses the degree of its pollution potentials and recommend appropriate treatment for the sewage.

\section{Materials and Methods}

\subsection{Source of Raw Sewage}

The raw sewage was obtained from a steady stream of sewage arriving at a central sewerage system (CSS) in an estate located in Warri, Delta State, Nigeria.

The central sewerage systems serve an average human population of 4,000 inhabitants. All the sewage systems from each house in the estate were connected to the CSS main stream through an inlet/outlet pipe. The raw sewage is carried by the central sewage system and discharged into a collection chamber at an average flow rate of $204 \mathrm{~m}^{3}$ per day.

Finally the sewage is channelled through a drainage system and disposed off in a nearby bush. 


\subsection{Sampling Techniques}

Samples were obtained from the estate weekly on different days of the week from Monday to Saturday beginning at $7.00 \mathrm{am}$ and ending at $12.00 \mathrm{pm}$ each day. The day for sample collection in the new week was different from that of the preceding week. This was done so that the total exercise might account for the cyclic and intermittent variations occurring at the work site.

Six samples were collected at hourly intervals. During sampling each sample was collected in a clean, well labelled colourless plastic bottle of 1 litre capacity and kept in a refrigerator maintained at $4{ }^{\circ} \mathrm{C}$. At this temperature, biodegradation is inhibited. The rate of flow was determined using a flow meter each time the samples were collected.

At the end of the sampling period, a composite sample was made by adding together volumes of the samples proportional to the rates of flow. The samples were collected in wet and dry seasons which are the major seasons in Nigeria so that the results obtained could give a full account of the sewage characteristics in the two seasons.

The sewage samples were used to determine electrical conductivity, suspended solids, permanganate value, biochemical oxygen demand and chemical demand and chemical oxygen demand.

\subsection{Methods of Analysis}

The samples were analysed as described in the Standard Methods for the Examination of Water and Wastewater (APHA, 1995); Standard Method for Water and Effluents Analysis (Ademoroti, 1996b) and Bureau of Indian Standards (BIS, 2005). Where analysis was not immediately possible, they were preserved by refrigeration at $4{ }^{\circ} \mathrm{C}$.

\section{Results and Discussion}

\subsection{Result}

Results of characterization of domestic sewage obtained from the estate are as shown in Tables 1-3. The results represent mean values obtained from the determinations together with their standard deviations. Tables 1 and 2 represent the mean values obtained from the analysis in wet and dry season months. Table 3 shows a summary of both the dry and wet seasons in the whole year.

\subsection{Discussion}

The sewage analysed had high value for most of the characteristics in wet season. This means that during rainfall, storm water washes various materials (debris, etc) into the open collection chamber where the sewage from the central sewerage system flows into. The debris being washed in will definitely take toll on the characteristics determined. The low values recorded for most characteristics in dry season were due to the fact that no debris was washed into the open collection chamber. For electrical conductivity, mean values ranged from 231.33 to us/cm to $367.00 \mathrm{us} / \mathrm{cm}$ in the wet season and from $220.57 \mathrm{us} / \mathrm{cm}$ to $285.67 \mathrm{us} / \mathrm{cm}$ in the dry season. This shows that inorganic ions such as $\mathrm{H}^{+}, \mathrm{Na}^{+}, \mathrm{K}^{+}, \mathrm{Mg}^{2+}, \mathrm{Ca}^{2+}, \mathrm{Cl}^{-}, \mathrm{SO}_{4}{ }^{2-}, \mathrm{HCO}_{3}{ }^{-}$etc. are present in reasonable concentrations in the sewage. These ions have a major influence on the conductivity. The slight increase in conductivity in the wet months could be due to slight increase in the mineral contents of the raw sewage during the wet season.

For dissolved solids, mean values in the wet season ranged from $140.00 \mathrm{mg} / \mathrm{L}$ to $206.00 \mathrm{mg} / \mathrm{L}$ while in the dry season months values ranged from $100 \mathrm{mg} / \mathrm{L}$ to $140.00 \mathrm{mg} / \mathrm{L}$. This shows the amount of matter dissolved in the sewage. Substances dissolved often contain proteins, carbohydrates, esters and mineral salts. Some organic matter due to storm water washed into the collection chamber during the wet season would have been broken down and dissolved in the sewage. This would have been responsible for the higher levels of dissolved solids in the sewage during the wet season compared with the dry season.

Values of suspended solids ranged form $200.00 \mathrm{mg} / \mathrm{L}$ to $380.00 \mathrm{mg} / \mathrm{L}$ for the wet season months and $200.00 \mathrm{mg} / \mathrm{L}$ to $280.00 \mathrm{mg} / \mathrm{L}$ in the dry season months. The SS values also show the amount of oxygen demand exerted by the organic and inorganic solids present as suspended matter in the sample. The higher level of suspended solids in the wet season months could mean that there are high levels of BOD present in the sewage during the wet season which would deplete the dissolved oxygen present in the water where the raw sewage would flow into (Gaudy \& Gaudy, 1980). Also low values of SS in the dry season months could be due to the fact that as the water flowed most of the solid particles were broken down and dissolved in the water. The suspended solid content of domestic sewage of medium strength ranges between $200 \mathrm{mg} / \mathrm{L}$ and $290 \mathrm{mg} / \mathrm{L}$ (Miroslav \& Vladimir, 1999).

For the Total solids, the values ranged from $332.00 \mathrm{mg} / \mathrm{L}$ to $580.00 \mathrm{mg} / \mathrm{L}$ during the wet season and from 300.00 $\mathrm{mg} / \mathrm{L}$ to $420.00 \mathrm{mg} / \mathrm{L}$ in the dry season. Total solids content is obtained by the addition of suspended solids and dissolved solids. It provides information on how much pollutants are present in the raw sewage. 
Thus the range of values obtained above reflects the characteristics discussed for both SS and DS.

Permanganate value also ranged from $162.20 \mathrm{mg} / \mathrm{L}$ to $286.00 \mathrm{mg} / \mathrm{L}$ in the wet season and $165.00 \mathrm{mg} / \mathrm{L}$ to 218.40 $\mathrm{mg} / \mathrm{L}$ in the dry season. These values provide information on the organic and in organic matter in the sewage that are readily available.

Therefore, it reflects the amount of oxygen that can be obtained from potassium permanganate to oxidize the readily oxidizable substances present in the sewage.

Biochemical oxygen demand values ranged from $190.37 \mathrm{mg} / \mathrm{L}$ to $220.74 \mathrm{mg} / \mathrm{L}$ in the wet season months and from $163.70 \mathrm{mg} / \mathrm{L}$ to $220.37 \mathrm{mg} / \mathrm{L}$ in the dry season months.

The BOD values obtained indicates the amount of organic pollution present in the raw sewage. It shows that discharge of the sewage into a receiving water body (river, stream, lakes, and oceans etc.) will lead to pollution due to organic, oxygen-demanding wastes present in the water. This will consequently lead to very high oxygen demand thereby causing harmful aesthetic effects such as objectionable odour and appearance in the water.

Aquatic life will be put under stress due to reduction in oxygen levels and fish would likely suffocate to death. (Miroslav \& Vladimir, 1999.)

For chemical oxygen demand, the values ranged from $286.22 \mathrm{mg} / \mathrm{L}$ to $355.56 \mathrm{mg} / \mathrm{L}$ in the wet season months and $286.22 \mathrm{mg} / \mathrm{L}$ to $336.00 \mathrm{mg} / \mathrm{L}$ in the dry season months. The COD values above reflect the biodegradable and non-biodegradable oxygen demand that is due to organic matter present in the sample.

\section{Conclusion}

The results obtained from the analysis show that the domestic sewage is of medium strength. This means that the sewage has some pollution potentials and therefore needs to be treated before disposal and reuse for agricultural purposes. Treatment of the sewage will help to reduce pathogens eliminate offensive odours and inhibit or eliminate the pollution potentials so as to create a good and healthy environment. Treatment must be carried out in a treatment plant with the basic components that accompany the combined treatment process.

\section{References}

Ademoroti, C.M.A. (1996a). Environmental Chemistry \& Toxicology, Foludex Press Ltd., Ibadan.

Ademoroti, C.M.A. (1996b). Standard Methods for Water and Effluents Analysis, Foludex Press Ltd., Ibadan.

APHA. (1995). Standard Methods for the Examination of Water and Wastewater, $19^{\text {th }}$ Edition, American Public Health Association, New York.

Bureau of Indian Standards. (BIS). (2005). Methods of Sampling and Test for Water and Wastewater, $1^{\text {st }}$ Revision of 1530025 ICS No. 13.060.50.

Fox, J.C. and Gerald, P.R. (1981). Sewage Microorganisms: A color Atlas, Lewis Publisher, Chelsea, MI.

Geldreich, E.E. (1978). Bacterial Population and Indicator Concepts in Faeces, Sewage, Stormwater and Solid Waste in Indicators of Viruses in Water and Food.

Henry, J.G and Heinke, G.W. (1989). Environmental Science and Engineering, Prentice Hall, Eaglewood Cliffs, N.J.

Metcalf and Eddy Inc. (2001). Wastewater Engineering: Treatment, Disposal and Reuse, $3^{\text {rd }}$ Ed., McGraw - Hill Publishing Company Ltd., $3^{\text {rd }}$ Ed., New York.

Miroslav, R and Vladimir, B.N. (1999). Practical Environmental Analysis, The Royal Society of Chemistry, Cambridge, UK.

Porteous, A. (2000). Dictionary of Environmental Science and Technology; $3^{\text {rd }}$ Edition, John Wiley and Sons Ltd., England.

Snoeyink, V.L and Jenkins, D. (1980). Water Chemistry, $2^{\text {nd }}$ Edition, John Wiley and Sons, New York.

Steward, J.W. and Towse, P.J. (1984). Chemical Technology in Africa, A Resource Book P.J. Cambridge University press, London

Weber, W.Jr. (1972). Physical - Chemical Processes for Water Quality Control. 
Table 1. Data computation of domestic sewage from studied site in Warri for wet season months (April -October)

\begin{tabular}{|c|c|c|c|c|c|c|c|c|}
\hline \multirow[b]{2}{*}{$\mathbf{S} / \mathbf{N}$} & \multirow[b]{2}{*}{ MONTHS } & \multicolumn{7}{|c|}{ Mean values for wet season months } \\
\hline & & $\begin{array}{c}\text { EC } \\
(\mathrm{uS} / \mathrm{cm}) \\
\operatorname{mean} \pm \mathrm{SD}\end{array}$ & $\begin{array}{c}\text { DS } \\
(\mathrm{mg} / \mathrm{L}) \\
\text { mean } \pm \text { SD }\end{array}$ & $\begin{array}{c}\mathrm{SS} \\
(\mathrm{mg} / \mathrm{L}) \\
\operatorname{mean} \pm \mathrm{SD}\end{array}$ & $\begin{array}{c}\text { TS } \\
(\mathrm{mg} / \mathrm{L}) \\
\text { mean } \pm \text { SD }\end{array}$ & $\begin{array}{c}\text { PV } \\
(\mathrm{mg} / \mathrm{L}) \\
\text { mean } \pm \text { SD }\end{array}$ & $\begin{array}{c}\text { BOD5 } \\
(\mathrm{mg} / \mathrm{L}) \\
\text { mean } \pm S\end{array}$ & $\begin{array}{c}\text { COD } \\
(\mathrm{mg} / \mathrm{L}) \\
\text { mean } \pm \text { SD }\end{array}$ \\
\hline 1. & APRIL & $348.00 \pm 0.94$ & $348.00 \pm 0.94$ & $380.00 \pm 1.89$ & $580.00 \pm 7.23$ & $286.00 \pm 34.10$ & $216.30 \pm 6.96$ & $344.89 \pm 8.43$ \\
\hline 2. & MAY & $313.00 \pm 2.45$ & $313.00 \pm 2.45$ & $260.00 \pm 2.11$ & $440.00 \pm 3.46$ & $194.80 \pm 0.43$ & $204.07 \pm 6.83$ & $334.22 \pm 5.33$ \\
\hline 3. & JUNE & $268.00 \pm 6.83$ & $268.00 \pm 6.83$ & $240.00 \pm 271$ & $380.00 \pm 6.78$ & $166.40 \pm 1.26$ & $190.37 \pm 6.37$ & $323.56 \pm 7.06$ \\
\hline 4. & JULY & $231.33 \pm 0.47$ & $231.33 \pm 0.47$ & $200.00 \pm 2.31$ & $332.00 \pm 4.00$ & $162.20 \pm 0.80$ & $194.08 \pm 2.22$ & $286.22 \pm 5.33$ \\
\hline 5. & AUGUST & $269.00 \pm 3.56$ & $269.00 \pm 3.56$ & $250.00 \pm 189$ & $411.33 \pm 3.53$ & $175.80 \pm 5.12$ & $220.74 \pm 3.44$ & $318.22 \pm 9.61$ \\
\hline 6. & SEPTEMBER & $367.00 \pm 4.67$ & $367.00 \pm 4.67$ & $256.00 \pm 2.98$ & $462.00 \pm 4.00$ & $219.27 \pm 0.85$ & $211.85 \pm 5.56$ & $355.56 \pm 25.02$ \\
\hline 7. & OCTOBER & $278.33 \pm 2.71$ & $278.33 \pm 2.71$ & $260.00 \pm 4.99$ & $400.00 \pm 8.99$ & $217.27 \pm 0.19$ & $200.37 \pm 3.67$ & $321.78 \pm 12.51$ \\
\hline
\end{tabular}

Table 1 above depicts the characteristics of domestic sewage from the study site in Warri between the month of April and October which will represents the wet season. The values are the mean of triplicate determinations. The essence of this study is to know the status of the sewage during the wet season.

Table 2. Data computation of domestic sewage from studied site in Warri for dry season months (November-March)

\begin{tabular}{|c|c|c|c|c|c|c|c|c|}
\hline & & \multicolumn{7}{|c|}{ Mean values for dry season months } \\
\hline $\mathbf{S} / \mathbf{N}$ & MONTHS & $\begin{array}{c}\text { EC } \\
(\mathrm{uS} / \mathrm{cm}) \\
\text { mean } \pm \mathrm{SD}\end{array}$ & $\begin{array}{c}\text { DS } \\
(\mathrm{mg} / \mathrm{L}) \\
\text { mean } \pm \text { SD }\end{array}$ & $\begin{array}{c}\text { SS } \\
(\mathrm{mg} / \mathrm{L}) \\
\text { mean } \pm \text { SD }\end{array}$ & $\begin{array}{c}\text { TS } \\
(\mathrm{mg} / \mathrm{L}) \\
\text { mean } \pm \text { SD }\end{array}$ & $\begin{array}{c}\text { PV } \\
(\mathrm{mg} / \mathrm{L}) \\
\text { mean } \pm \mathrm{SD}\end{array}$ & $\begin{array}{c}\text { BOD5 } \\
(\mathrm{mg} / \mathrm{L}) \\
\text { mean } \pm \mathrm{S}\end{array}$ & $\begin{array}{c}\text { COD } \\
(\mathrm{mg} / \mathrm{L}) \\
\text { mean } \pm \text { SD }\end{array}$ \\
\hline 1. & NOVEMBER & $220.57 \pm 4.45$ & $220.57 \pm 4.45$ & $200.00 \pm 2.83$ & $300.00 \pm 4.00$ & $165.00 \pm 0.85$ & $163.70 \pm 9.09$ & $298.67 \pm 19.23$ \\
\hline 2. & DECEMBER & $222.33 \pm 2.26$ & $222.33 \pm 2.26$ & $214.00 \pm 9.09$ & $314.00 \pm 9.71$ & $168.53 \pm 0.44$ & $166.61 \pm 1.68$ & $286.22 \pm 12.51$ \\
\hline 3. & JANUARY & $241.67 \pm 9.17$ & $241.67 \pm 9.17$ & $220.00 \pm 11.03$ & $340.00 \pm 12.80$ & $182.73 \pm 0.64$ & $180.74 \pm 4.38$ & $302.22 \pm 2183$ \\
\hline 4. & FEBRUARY & $260.44 \pm 2.59$ & $260.44 \pm 2.59$ & $250.00 \pm 1.33$ & $374.00 \pm 3.40$ & $202.73 \pm 0.34$ & $189.37 \pm 9.09$ & $318.22 \pm 18.67$ \\
\hline 5. & MARCH & $285.67 \pm 3.23$ & $285.67 \pm 3.23$ & $280.00 \pm 6.11$ & $420.00 \pm 7.36$ & $218.40 \pm 0.57$ & $220.37 \pm 4.83$ & $336.00 \pm 8.00$ \\
\hline
\end{tabular}

Table 2 above depicts the characteristics of domestic sewage from the study site in Warri between the month of November and March which will represents the dry season. The values are the mean of triplicate determinations. The essence of this study is to know the status of the sewage during the dry season. 
Table 3. Data computation of domestic sewage from studied site in Warri.

\begin{tabular}{|c|c|c|c|c|c|c|c|c|}
\hline $\mathbf{S} / \mathbf{N}$ & MONTHS & $\begin{array}{c}\text { EC } \\
(\mathrm{uS} / \mathrm{cm}) \\
\text { mean } \pm \text { SD }\end{array}$ & $\begin{array}{c}\text { DS } \\
(\mathrm{mg} / \mathrm{L}) \\
\text { mean } \pm \text { SD }\end{array}$ & $\begin{array}{c}\mathrm{SS} \\
(\mathrm{mg} / \mathrm{L}) \\
\text { mean } \pm \text { SD }\end{array}$ & $\begin{array}{c}\text { TS } \\
(\mathrm{mg} / \mathrm{L}) \\
\text { mean } \pm \text { SD }\end{array}$ & $\begin{array}{c}\text { PV } \\
(\mathrm{mg} / \mathrm{L}) \\
\text { mean } \pm \text { SD }\end{array}$ & $\begin{array}{c}\text { BOD }_{5} \\
(\mathrm{mg} / \mathrm{L}) \\
\text { mean } \pm S\end{array}$ & $\begin{array}{c}\text { COD } \\
(\mathrm{mg} / \mathrm{L}) \\
\text { mean } \pm \text { SD }\end{array}$ \\
\hline 1. & APRIL & $348.00 \pm 0.94$ & $348.00 \pm 0.94$ & $380.00 \pm 1.89$ & $580.00 \pm 7.23$ & $286.00 \pm 34.10$ & $216.30 \pm 6.96$ & $344.89 \pm 8.43$ \\
\hline 2. & MAY & $313.00 \pm 2.45$ & $313.00 \pm 2.45$ & $260.00 \pm 2.11$ & $440.00 \pm 3.46$ & $194.80 \pm 0.43$ & $204.07 \pm 6.83$ & $334.22 \pm 5.33$ \\
\hline 3. & JUNE & $268.00 \pm 6.83$ & $268.00 \pm 6.83$ & $240.00 \pm 271$ & $380.00 \pm 6.78$ & $166.40 \pm 1.26$ & $190.37 \pm 6.37$ & 323.56 \\
\hline 4. & JULY & $231.33 \pm 0.47$ & $231.33 \pm 0.47$ & $200.00 \pm 2.31$ & $332.00 \pm 4.00$ & $162.20 \pm 0.80$ & $194.08 \pm 2.22$ & 286.22 \\
\hline 5. & AUGUST & $269.00 \pm 3.56$ & $269.00 \pm 3.56$ & $250.00 \pm 189$ & $411.33 \pm$ & $175.80 \pm$ & $220.74 \pm 3.44$ & $318.22 \pm 9.61$ \\
\hline 6. & SEPTEMBER & $367.00 \pm 4.67$ & $367.00 \pm 4.67$ & $256.00 \pm 2.98$ & $462.00 \pm 4.00$ & $219.27 \pm 0.85$ & $211.85 \pm 5.56$ & $355.56 \pm 25.02$ \\
\hline 7. & OCTOBER & $278.33 \pm 2.71$ & $278.33 \pm 2.71$ & $260.00 \pm 4.99$ & $400.00 \pm 8.99$ & $217.27 \pm 0.19$ & $200.37 \pm 3.67$ & $321.78 \pm 12.51$ \\
\hline 8. & NOVEMBER & $220.57 \pm 4.45$ & $220.57 \pm 4.45$ & $200.00 \pm 2.83$ & $300.00 \pm 4.00$ & $165.00 \pm 0.85$ & $163.70 \pm 9.09$ & $298.67 \pm 19.23$ \\
\hline 9. & DECEMBER & $222.33 \pm 2.26$ & $222.33 \pm 2.26$ & $214.00 \pm 9.09$ & $314.00 \pm 9.71$ & $168.53 \pm 0.44$ & $166.61 \pm 1.68$ & $286.22 \pm 12.51$ \\
\hline 10. & JANUARY & $241.67 \pm 9.17$ & $241.67 \pm 9.17$ & $220.00 \pm 11.03$ & $340.00 \pm 12.80$ & $182.73 \pm 0.64$ & $180.74 \pm 4.38$ & $302.22 \pm 2183$ \\
\hline 11. & FEBRUARY & $260.44 \pm 2.59$ & $260.44 \pm 2.59$ & $250.00 \pm 1.33$ & $374.00 \pm 3.40$ & $202.73 \pm 0.34$ & $189.37 \pm 9.09$ & $318.22 \pm 18.67$ \\
\hline 12. & MARCH & $285.67 \pm 3.23$ & $285.67 \pm 3.23$ & $280.00 \pm 6.11$ & $420.00 \pm 7.36$ & $218.40 \pm 0.57$ & $220.37 \pm 4.83$ & $336.00 \pm 8.00$ \\
\hline
\end{tabular}

Table 3 above shows the characteristics of domestic sewage from the sewage treatment plant at the studied site in Warri for the whole year. The values are the mean of triplicate determinations. The essence of this study is to know the status of the sewage from the treatment plant for the whole year. 